\section{Demonstrating value}

What if you could demonstrate the value of treatment to patients? Now you can with the EXTARO 300 dental microscope supplied by Nuview. It features an integrated HD camera that wirelessly records images and videos to the ZEISS Connect App, where these files can be directly transferred to your local network.

Through this platform, practitioners can show patients images and videos of their past and current condition, highlighting areas that potentially require treatment. This facilitates improved communication and engagement, enabling patients to make more informed decisions about proposed treatment to increase case acceptance.

Call the professional team at Nuview for further details.

For more information call Nuview on 01453 872266, email info@nuview-ltd.com, visit www.nuview.co or 'like' Nuview on Facebook.

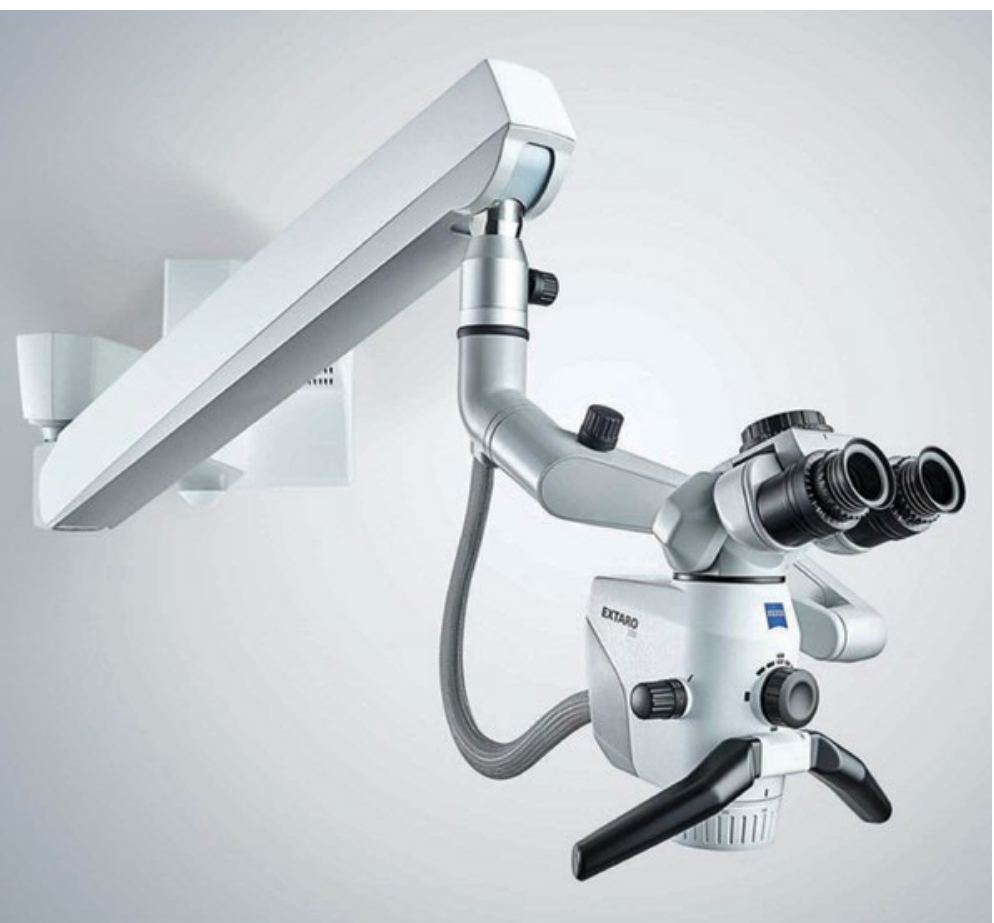

\section{Adopt don't shop!}

Are you looking for high-quality breakdown cover and maintenance for your dental air compressor, but don't want to purchase a new piece of equipment?

Adopt don't shop and let DentalAir look after your existing dental air compressor with its AirCare Adoption Programme.

For a fixed monthly fee, DentalAir will provide comprehensive care for your air compressor, including regular servicing visits and always making sure that it remains compliant with NHS HTM 2022/1 standards. This will ensure that the equipment passes any CQC inspections too.

Give your existing air compressor the care it deserves by choosing DentalAir.

For more information, contact DentalAir at info@dentalair. com or call 08009757530 .

\section{A cleaner and disinfectant with a 1-minute contact time}

OPTIM 1 is the market-leading wipe in North America, now available in Europe.

OPTIM 1 wipes:

- Clean and disinfect, with a 1-minute contact time

- Are gentle and non-toxic and will not irritate the eyes, skin, or respiratory system

- Are compatible with a range of hard, non-porous materials and surfaces

- Have hydrogen peroxide as the active ingredient, which breaks down into water and oxygen, making them kind to the environment

- Have been tested and passed for all major dental chair upholstery for added protection.

OPTIM 1 wipes are effective against difficult-to-kill pathogens, including COVID-19 (coronavirus).

Available from SciCan, recently acquired by COLTENE.

For information about OPTIM 1 visit: https://www.scican. com/eu/products/cleaners-disinfectants/optim-1/.

www.coltene.com, email info.uk@coltene.com or call 01444235486

\section{Special offer online seminars}

With our daily lives turned upside down by the current situation, is now the perfect time to develop your knowledge in areas you have always wanted?

S4S Dental Laboratory is offering $50 \%$ off all online seminars. Gain six hours of enhanced continuing professional development (ECPD) and grow your knowledge in the areas of snoring and sleep apnoea, bruxism and Smilelign clear aligners. Usually priced at $£ 195$ per seminar, use code 3909 to receive $50 \%$ off. Download now at s4s.co/onlineseminars.

\section{Outstanding educational resources}

Leading oral healthcare specialist, Curaden, is delighted to launch its \#EducationNeverStops campaign, which aims to provide outstanding educational resources to support dental professionals during this most challenging of times.

As part of this inspirational campaign, a live webinar will be held every day between 30 March and 3 April on the Curaden Academy website. These sessions provide a fantastic platform for you to explore a variety of interesting topics presented by leading industry experts, professors, specialists and doctors.

With the chance to learn something new, such webinars will enable you to prepare to return to practice with renewed knowledge, enthusiasm and passion for delivering top-quality patient care.

Register your interest today - you won't want to miss out! For further details, visit www.curadencampus.com. 